\title{
MODEL OF PUBLIC ACCOUNTABILITY FOR PUBLIC DEBT REDUCTION IN PUBLIC INTEREST
}

\author{
URSZULA K. ZAWADZKA-PĄK
}

\begin{abstract}
In the financial context of public interest, the attention should be paid to the public debt, especially in the intergenerational perspective of justice. Thus, the aim of the paper is to present the theoretical, multidimensional model of accountability for public debt that will serve in public interest. The research question is what is the nature of conditions necessary to the effective limitation of public debt. According to the research hypothesis, these conditions are of varied nature, they are not limited to the legal dimension of legal responsibility but they have the basis in the public accountability. To achieve the scientific aim of the research and to search for the evidence to support the study's hypothesis the literature review was made, consisting in the analysis of the existing literature presenting the theoretical and empirical results of the previous research. We conclude that to effectively reduce public debt, the multidimensional model of public debt should be developed, consisting of four components i.e.: the legal responsibility, the democratic accountability, the moral accountability, the financial accountability. Having the knowledge on the particular components of the proposed model it would be possible in future research to analyze the components of the politicians' motivation to issue the regulations in accordance with universally binding moral rules serving the public interest and not their own interests (the legal motivation).
\end{abstract}

\section{Keywords}

Public interest; legal regulation; public values; democratic values

\section{JEL Classification: A13, H30, H63}

1 Doctor of Law, Department of Public Finances and Financial Law, Faculty of Law, University of Bialystok, Poland. The author specializes in financial law and public financial management, including participatory budgeting, public values, fiscal rules and performance management. She is the author or co-author of 7 books and more than 75 papers or books chapters. Member of Centre for the Research on the Public Finances and Tax Law in the Countries of Central and Eastern Europe, International Political Science Association and European Economic Association. More information can be found on her website: uzawadzka.org. Contact email: u.zawadzka@uwb.edu.pl. 


\section{Introduction}

Public interest-based theories are imprecise because the subject of these theories is an ideal rather than a discrete construct (Fesler, 1990). The concept of public interest is sometimes identified with public values, however, the most important distinction between these two concepts is that "public interest" is an ideal, whereas "public values" have specific, identifiable content. In particular context, the public interest refers to the outcomes best serving the long-run survival and wellbeing of a social collective construed as a "public" (Bozeman, 2007: 12). In consequence, in the financial context of public interest, the attention should be paid on the public debt, especially if we take into consideration the intergenerational perspective. In such a case it takes the form of the sustainability that requires the protection of wealth across generations (Norton, 2017: 355). J. Rawl, one of the most influential moral and political philosopher in the liberal tradition, presenting his theory of the intergenerational justice claims that "persons in different generations have duties and obligations to one another just as contemporaries do" (Rawl, 1999: 258).

The level of public debt is one of the crucial, even if not the only one, determinants of the public finance sustainability, understood as the capacity to incur future financial burdens arising from the current debt (Fiscal Sustainability Report 2012: VII). Even if current generations of citizens (and voters) may be pleased by the public debt accumulation used to finance public services, the excessive indebtedness may be dangerous for future generations. In extreme cases the excessive level of public debt decides about the undisturbed existence of states; significant public debt was one of the reasons for the bankruptcy of Argentina, the problems thereof are being compared with the current situation of Greece. Even if there is no doubt that the reduction of the public debt level is in public interest, the public authorities of some countries are effective in that and the other not. The Figure 1 presents the data on the public debt in relation to GDP in the selected European countries in 2005, i.e. before the financial crisis, in 2010, just after its end (even if the delimitation of precise time frame uniformly for all the countries is difficult), and currently (the latest data come from 2015). 
Figure 1 Public Debt in Selected European Countries (as the percentage of GDP)

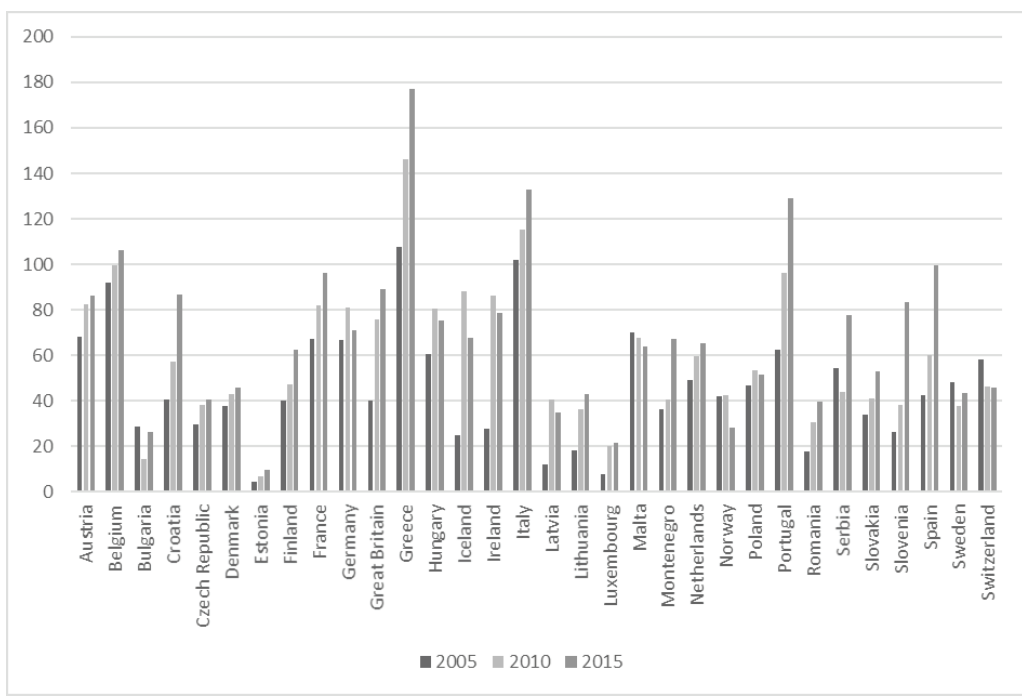

Source: Own elaboration on the basis of data of International Monetary Funds.

The study is composed of six sections, Having presented the overview of the public debt problem (section 1) and the adopted methodology (section 2) we present the literature review analyzing causes and the possible solutions to the public debt accumulation (section 3). That will enable to propose the conceptual framework of the multidimensional model of accountability for public debt (section 5). Our conclusion provides some general implications for law-making.

\section{Methodology}

Despite the efforts to broaden interdisciplinary scholarship, the traditional disciplines that comprise the "law-and" universe are mostly insular (Eisenberg, 2011; Bornstein, 2016: 119). This study proposes the theoretical framework for interdisciplinary research to make the better law, the law informed by reality, i.e. evidence-based law (Rachlinski, 2011: 910). In more details, the aim of the paper is to present the theoretical, multidimensional model of accountability for public debt that will serve in public interest. The research question is what is the nature of conditions necessary to the effective limitation of public debt. According to the research hypothesis, these conditions are of varied nature, they are not limited to the legal dimension of legal responsibility but they should have the basis in the public accountability. To achieve the scientific aim of the research and to search for evidence to support the study's hypothesis the literature review was made (Fink, 
2014: 6), thus the unobtrusive method (Babbie, 2007) consisting in particular in the analysis of the existing literature presenting the theoretical and empirical results of the previous research was applied.

The considerations presented in this chapter constitute the pure (conceptual) research, developing new concepts and reinterpreting the existing ones (Kothari, 2004: 4-5), i.e. the preliminary theory of the multidimensional accountability for public debt reduction. As it results from the Figure 2, within the pure legal research, there are two types of research styles, i.e. the traditional legal theory research and the interdisciplinary fundamental research. In the study, we go beyond the limits of traditional legal research theory and we use the interdisciplinary fundamental research. However, to test empirically the proposed model and to draw the detailed conclusions for the evidence-based law, effective in the public debt reduction (conclusions de lege lata and de lege ferenda) the future interdisciplinary research will be needed, this time using the quantitative and qualitative methods.

Figure 2 Legal Research Styles

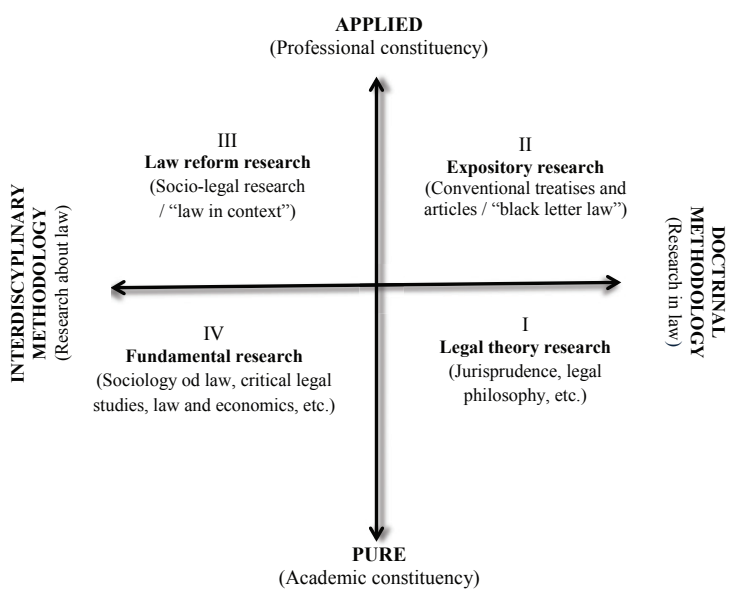

Source: H.W. Arthurs (1983) as cited by A. Knight, L. Ruddock (2008: 29).

\section{Public Debt - Causes and Solutions}

\subsection{Legal Regulations as Cause and Solution to Public Debt Accumulation}

One of the main reason of the public debt is the existence of the public deficits in the consecutive years that, in turn, results from the excessive public expenditure 
that are not covered sufficiently by the annual public revenues. The significant part of public expenditure is legally determined (Dębowska-Romanowska, 2010: 130). Hence, the literature proposes to reduce their share in the structure of the budget and opt more for the flexible expenditure as well as to limit the amount of expenditure from the budget of total funds (Dębowska-Romanowska, 2007: 292). To solve these problems already Buchanan and Wagner (1977) proposed the use of constitutional fiscal rules. Nowadays actually the public authorities try to reduce public debt by these rules, even if rarely having the constitutional rank (ZawadzkaPąk, 2018: 213-228) Fiscal rules typically are defined as the numerical or procedural restrictions on the preparation, approval, and implementation of public budgets (Corbacho, Ter-Minssian, 2013: 38). These rules cover summary fiscal indicators, such as the government budget deficit, borrowing, debt, or major components thereof - expressed as a numerical ceiling or target, in proportion to the gross domestic product, GDP or being procedural limitations (Kopits, Symansky, 1998: 15; Corbacho, Ter-Minassian, 2013: 40). As it results from the research conducted by the International Monetary Fund, the majority of countries in the world has introduced some kind of fiscal rules (Fiscal Rules Dataset 1985-2015, IMF 2016), however as it results from the Figure 1. in some countries the fiscal rules are effective and in other not. However, there are numerous analysis showing that these formal constraints on fiscal policy, even at the constitutional level, do not prevent the excessive debt (Ayuso-i-Casals, et al.: 2009) or encourage politicians to go around these regulations (Hagen, 1991).

\subsection{Democracy as Cause and Solution to Public Debt Accumulation}

The link between democracy and public debt has begun to be recognized in the seventeenth century (Macdonald, 2003). Buchanan and Wagner (1977) has also noted that democracies find it difficult to maintain financial discipline. However, the reduction of public debt and deficit technically is not difficult. The lack of political will in this regard is linked to the essence of a democratic system. The policy-makers are chosen by citizens, so aspiring to take or maintain power they make expensive promises and then they pass the laws allowing them to be reelected, what often is harmful to the public debt level, reflecting the politicians' long-term consequences of budgetary decisions. R. Hannesson (2015: 13) argues that democracy is better at distributing wealth widely than in generating it in the first place and is wondering if it carries within itself the seeds of its own destruction. This is supported by the fiscal illusion theory, espoused by J.M. Buchanan and R.E. Wagner (1977). According to this theory, the politicians, as vote maximizers, tend to propose new government programs to attract new voters as much as possible, which makes public sector bigger. They are motivated to "fool" citizens 
so that they may attract individuals' votes without being blamed for the increase in government spending. By designing and manipulating the fiscal system, politicians try to make the public underestimate the costs of public sector goods and services. The greater the extent of these "illusion-inducing" characteristics of a fiscal system, the greater the size of the government. In this sense, the democratic political system where the citizens' representatives in parliament are chosen in the election, seems to be the cause of the public debt accumulation. The above is strictly related to the political business cycles theory that implies that governments, in order to be reelected try harder to please voters immediately before election day (Breton, 1974). As R. Hannesson (2015) argues "elites are voted into power, or kept in power, by a mostly uninformed electorate that votes for them in the expectation that they will govern well, which mostly means high and rising standards of living. When the elites fail to deliver, they are voted out (...) But raising taxes is not popular (...) The temptation to finance an expanding government sector by increasing debt is therefore strong" (Hannesson, 2015).

On the other hand, the democracy may be seen as a solution to the excessive public debt accumulation. The relations between public debt and the level of democracy are widely analysed in the literature, even if not ambiguous (Feld, Kirchgässner, 2001; Holland, 2016; Stallings, Kaufman, 1988; Frieden, 1985: 300; Cheru, 1989), in some papers being restricted to precious legal analysis but not supported by quantitative proofs (Schragger, 2012), in other works being limited to singlecase analysis (Lindholm, 1946); (Chossudovsky, Ladouceur, 1994: 1506-1507). Also, contributions based on the statistical methods give ambiguous results, thus still require more attention. For instance, G. Anderson (1988) using a simple model supports the thesis that the external public debt levels will be higher in the dictatorship. Next, E.M. Balkan and K.V. Greene (1990: 211) denying the Anderson's contribution and using larger, but still limited, sample of countries and the statistical analysis found little empirical support for the thesis that democracy or autocracy influence foreign debt (Balkan, Greene, 1990). On the other hand T. Oatley (2010: 195) provides the statistical pieces of evidence that the autocratic governments accumulated substantially larger foreign debt relative to their national income than democratic governments. Moreover, the studies have shown that the direct democracy (financial referendum) contributes to a reduction of public debt in Switzerland (Feld, Kirchgässner, 2001). It has also been also proven that the financial referendum in Switzerland contributes to reduction of public debt by limiting by the citizens the growth of social spending, as citizens deciding on public money (in fact on taxes that they pay) are much more economical in that regard than the political elites (Kriesi, Trechsel 2008: 164). In contrast to these Swiss experiences, the pieces of evidence from German municipalities suggest that that direct democracy causes an expansion of local government expenditure (Asatryan, 2016). 
Model of Public Accountability for Public Debt Reduction in Public Interest

3.3 Public Values as Cause and Solution to Public Debt Accumulation

Nowadays, even not without difficulty, the need to combine the legal norms and the moral ones, known since Greek times, is seen again. It was noticed that law deprived of moral attitudes is not able to properly direct citizens to the common good (Dudkiewicz, 2001: 186). Regardless of the dispute about the mutual relations between law and ethics (i.e. the science of morality), both these concepts lay at the heart of the idea of a democratic society (Fulek, 2009: 79. The essence of a democratic legal state seems to be, among others, that such a state should be "moral" and pass moral norms only in a universal "human" sense of this word (Zimmermann, 2013: 81). Legal norms should have their axiological justification, they should be embedded in values (Ziembiński, 1980: 137).

The Rawl's (1999) theory of the intergenerational justice, mentioned in the introduction as the basis of the public debt reduction in the public interests concept is based implicate on at least one of the public values, i.e. justice. On the other hand, the literature provides pieces of evidence that the violation of public values leads to the higher public debt. For instance, C. Liu, T.T. Moldogaziev, J. L. Mikesell (2017: 681) suggest that the levels of public debt issued by state and local governments appear to be higher as corruption levels increase. In consequence, it seems that to resolve the problem there is a need to determine the catalog of public values significant for public debt reduction, and next to find the means to shape appropriately these values by legal norms, as proposed by L. Petrażycki (1959: 200-213).

\subsection{Economic Doctrines as Causes and Solutions to Public Debt Accumulation}

Undoubtedly, the economic concept of the state realized by the policy-makers influences the public debt. For instance, after the First World War, increasing public expenditures and, consequently, public debt, were favored by the demands of state intervention (doctrine of interventionism). The influence of the realization of the welfare state concept was enhanced by the great economic crisis in 19291933 (Przybyciński, 2016: 30). Thus to reduce the public debt level being the consequence of the last financial crisis that in Europe took place in 2007-2008, the realization of the liberalism concept and the fiscal austerity measures are considered to be essential. However, others argue that fiscal austerity is selfdefeating, given its contractionary effect on output, and that reinvigorating growth through fiscal stimulus is more important (IMF, 2012: 101). Still, others suggest that the current problem of public debt could be resolved, as after World War II by the financial repression consisting in the channeling to the public sector funds that in a deregulated market environment would go elsewhere (Reinhart, Kirkegaard, 
Sbrancia, 2011). It seems thus interesting to know what is the most optimal concept of the public expenditures, especially in the relation to public revenues.

\subsection{Recapitulation of Cause and Effect Dimensions of Public Debt}

Figure 3 recapitulates the casual dimensions of public debt. This allows as to propose the multidimensional model of the accountability for public debt presented in the next section.

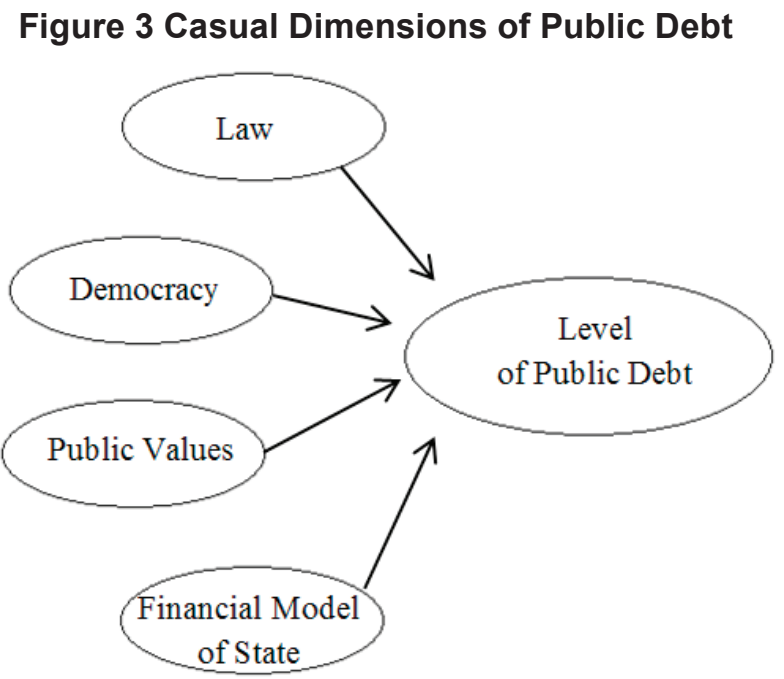

Source: Own elaboration.

\section{Responsibility and Accountability for Public Debt}

\subsection{Traditional Model of Responsibility for Public Debt and Multidimensional Model of Accountability for Public Debt}

Before presentation of the traditional model of responsibility and the multidimensional model of accountability for public debt reduction, let's explain the difference between the terms "responsibility" and "accountability". V.E. Barry (1979) has defined the term "responsibility", as referring to "a sphere of duty or obligation assigned to a person by the nature of that person's position, function, or work" Thus, the responsibility "could be viewed as a bundle of obligations associated with a job or function (...). In many cases, simply discharging this primary obligation (the function associated with the role) may be sufficient unto itself; however, responsibility can also include moral obligations that are in addition 
and usually related to the functional obligations of the role. Thus, responsibility assumes that the actor becomes also a moral agent possessed of a certain level of moral maturity and an ability to reason. (...). If responsibility is defined as a bundle of obligations, functional and moral, associated with a role, then accountability might be defined as blaming or crediting someone for an action - normally an action associated with a recognized responsibility" (www.freedomtocare.org) However as T. Bivins noted "a problem arises, however, in that while responsibility and accountability are often conflated, and admittedly importantly linked, they are not identical by definition or moral implication. The simplest formula is that a person can be held accountable if (1) the person is functionally and/or morally responsible for an action, (2) some harm occurred due to that action, and (3) the responsible person had no legitimate excuse for the action. Ideally, the assumption would then be to hold a person who is responsible for an action also accountable for the results of that action. That, however, may not always be the case. This position assumes that the responsible person is relatively autonomous, or free to make decisions associated with his or her job without outside pressure or influence" (Bivins, 2006: 20-21). In the literature two main usages of "accountability" can be observed. In the dominant usage of accountability is as a social, administrative, or political mechanism, conceptualized as an institutional relation or arrangement in which an agent can be held to account by another agent or institution. In the second usage, accountability is seen as a virtue, as a desirable quality of states, governments organizations, firms, or officials (Bovens, Schillemans, Goodin, 2015: $7-10)$.

As mentioned in section 3.2, the traditional model of responsibility for the public debt, illustrated in Figure 4, comprises only one dimension, i.e. the legal responsibility realized mainly via the fiscal rules.

Figure 4 Traditional Model of Legal Responsibility for Public Debt

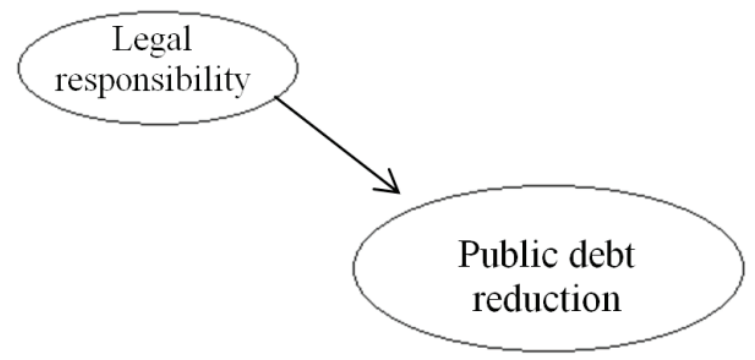

Source: Own elaboration. 


\subsection{Multidimensional Model of Accountability for Public Debt}

The fiscal rules aiming at the public debt reduction generally become ineffective if they are based only on the legal provisions as they may not be severe enough (e.g. if they only project but not oblige to respect the public finance variables, i.e. the level of public deficit, expenditure or debt), not stable enough (e.g. if they are in form of the legal act that can be modified or replaced by the simple parliamentary majority when becomes too severe), or not enough binding (e.g. if they have the form of the coalition agreement). That leads us to the conclusion that to limit the public debt much more effectively, the content of legal provisions on fiscal rules should be built the appropriate dimensions of the public accountability. Thus, we propose the multidimensional model of public debt reduction combining the elements of the responsibility and the accountability (as illustrated on Figure 5).

Figure 5 Multidimensional Model of Accountability for Public Debt

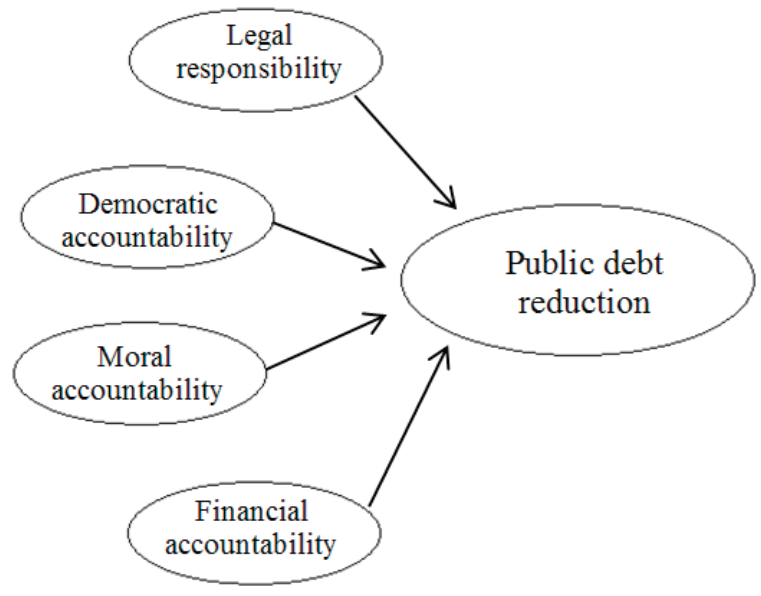

Source: Own elaboration.

Thus, the proposed model consists of four components i.e.:

- the legal responsibility resulting from broadly understood national and international legal norms regulating the fiscal rules and legal instruments supporting their effectiveness (e.g. fiscal councils);

- the democratic accountability resulting from a properly shaped democratic system, including the elements of electoral, liberal, deliberative, participatory, and egalitarian democracy;

- the moral accountability resulting from moral norms and values internalized by citizens and their representatives, i.e. the policy makers (the politicians). The moral accountability requires a change in the human paradigm (both, the 
politicians and the citizens), though not entirely rational, but often motivated by selfish motives (lat. homo-economic), in favour of a man (politician and citizen) guided by moral values (lat. homo ethicus) (Ossowska, 1971: 196; Misztal, 2017). The adoption of the homo ethicus attitude requires a broadly understood attitude of patriotism attribute an intrinsic moral value to the defense of the homeland (Clift, Woll, 2013). Financial patriotism is a derivative of many values and implies an accountable attitude for the public debt of both citizens and politicians, and submission goals important for a country over the personal will base on the solidarity with its own nation and community, social and intergenerational bonds;

- the financial accountability for shaping the appropriate level of public income, expenditure, and balance (in the relation to GDP). Financial dimension of the proposed model has the twofold characteristic, i.e. of the responsibility and the accountability. The first one appears when legal regulations (fiscal rules) oblige public authorities to respect legal limits of public debt, public deficit, public expenditures, or much less frequently, to maintain the minimal level of the public revenues. As this aspect of the financial dimension results from legal provisions, it takes part of the already mentioned dimension of the legal responsibility. On the other hand, the financial accountability of the proposed model consists in the political decisions of the legislators to take the appropriate decisions on fiscal policy.

\section{Conclusions}

All the four components of the model for accountability for the public debt can be operationalized by the variables, the values thereof are determined in the comparative datasets prepared by the international organizations or the research institutes. Testing the proposed model via the interdisciplinary research methods, in particular, quantitative one, on the sample of the groups of appropriately selected countries should lead for developing the theory of accountability for the public debt. The theory would be used to evidence-based law and in consequence be crucial for the effectiveness of the law, in our case the creation and the application of legal provisions ensuring the sustainability of public finances. In consequence, the formulation of postulates de lega lata to improve the application of binding legal norms, and de lege ferenda proposals describing the (innovative hopefully) legal solutions shaping the accountable attitudes of the government and the citizens for the state of public debt.

Nowadays the main instruments of public debt reduction are covered by the legal dimension. However, the fiscal rules inscribed in the legal framework of many 
countries turn out to be ineffective. It seems that in the era of the informational globalization the reason of the ineffectiveness of fiscal rules does not result from the intellectual disabilities of the legislator (the politicians) or lack of the professional support but rather from the lack of motivation to limit themselves in further expenditure planning. Having the knowledge on the particular components of the proposed model it would be possible to analyze the components of the politicians' motivation to issue the regulations in accordance with universally binding moral rules serving the public interest and not their own interests, as we define as "the legal motivation". This concept refers to the commonly accepted in public management, public administration, organizational behavior or the economy term "public service motivation" (Koehler, Rainey: 2008) that however seems not to be analyzed from the legal point of view, whereas it seems to be crucial for the public interest concept.

\section{References}

Anderson, G.M.: Public finance in autocratic process: An empirical note, Public Choice no. 1 (1988).

Arthurs, H.W.: Law and Learning: Report to the Social Sciences and Humanities Research Council of Canada by the Consultative Group on Research and Education in Law, Ottawa: Social Sciences and Humanities Research Council of Canada, 1983.

Asatryan, Z.: The indirect effects of direct democracy: local government size and non-budgetary voter initiatives in Germany, International Tax and Public Finance no. 3 (2016), DOI:10.1007/ s10797-015-9380-1.

Ayuso-i-Casals, J., Deroose, S., Flores, E., Moulin, L. (eds.): Policy Instruments for Sound Fiscal Policies Fiscal Rules and Institutions, London: Palgrave Macmillan, 2009.

Babbie, E.: The Practice of Social Research, Wadsworth: Thomson Learning, 2007.

Barry, V.E.: Moral Issues in Business, Belmont: Wadsworth, 1979.

Balkan, E.M., Greene, K.V.: On Democracy and Debt, Public Choice no. 3 (1990).

Bivins, T.: Responsibility and Accountability, in: Fitzpatrick, K., Bronstein, C., Ethics in Public Relations: Responsible Advocacy, London: Sage, 2006.

Bornstein, B.H.: Law and Social Science: How Interdisciplinary Is Interdisciplinary Enough?, in: Willis-Esqueda, C., Bornstein, B.H. (eds.): The Witness Stand and Lawrence S. Wrightsman, Jr., Cham: Springer, 2016.

Bovens, M., Schillemans, T., Goodin, R.: Public Accountability, in: Bovens, M., Goodin, R.E., Schillemans, T. (eds.), The Oxford Handbook of Public Accountability, Oxford: Oxford University Press, 2015.

Bozeman, B.: Public Interest. Counterbalancing Economic individualism, Washington: Georgetown University Press, 2007. 
Model of Public Accountability for Public Debt Reduction in Public Interest

Breton, A.: The economic theory of representative government, London: Palgrave Macmillan, 1974.

Buchanan, J.M., Wagner, R.E.: Democracy in Deficit: The Political Legacy of Lord Keynes, Carmel: Liberty Fund, 1977.

Cheru, F.: The Silent Revolution In Africa: Debt, Development, And Democracy, Vancouver: Anvil Press, 1989.

Chossudovsky, M., Ladouceur, M.: Debt and Democracy in Brazil, Economic and Political Weekly no. 25 (1994).

Chynoweth, P.: Legal Research, in: Knight, A., Ruddock, L. (eds.), Advanced Research Methods in the Built Environment, Chichester: Wiley-Blackwell, 2008.

Clift, B., Woll, C. (eds.): Economic Patriotism in Open Economies, Abingdon: Routledge, 2013.

Corbacho, A., Ter-Minassian, T.: Public Financial Management Requirements for Effective Implementation of Fiscal Rules, in: Allen, R., Hemming R., Potter, B.H. (eds.): The International Handbook of Public Financial Management, London: Palgrave Macmillan, 2013.

Dębowska-Romanowska, T.: Charakter prawny i klasyfikacja tzw. wydatków sztywnych a granice swobody politycznej władz państwa (Legal character and classification of the legally determined expenditure and the limits of political freedom of state authorities), in: Głuchowski, J., Pomorska A., Szołno-Koguc, J. (eds.), Uwarunkowania i bariery w procesie naprawy finansów publicznych (Conditions and barriers in the process of public finances reform), Lublin: KUL, 2007.

Dębowska-Romanowska, T.: Wydatki publiczne, ich formy prawne oraz zasady realizacji w sektorze finansów publicznych (Public expenditures, their legal forms and rules of implementation in public finance sector), in: Ruśkowski, E. (ed.), System prawa finansowego, t. 2. Prawo finansowe sektora finansów publicznych (Financial law system, vol. 2. Financial law of the public finance sector), Warszawa: Oficyna a Wolters Kluwer business, 2010.

Dutkiewicz, P.: Etyka a prawo (Ethics and law), in: Etyka, Kraków: Uniwersytet Jagielloński, 2001.

Eisenberg, T.E.: The origins, nature, and promise of empirical legal studies and a response to concerns, University of Illinois Law Review no. 5. (2011).

Feld, L.P., Kirchgassner, G.: Does Direct Democracy Reduce Public Debt? Evidence from Swiss Municipalities, Public Choice no. 3 (2001).

Fesler, J.: The state and its study: The whole and the parts, in: Lynn, N., Wildavsky, A. (eds.), Public administration: The state of the discipline, Chatham: Chatham House, 1990.

Fink, A.: Conducting Research Literature Review. From the Internet to Paper, Los Angeles, London, New Delhi, Singapore, Washington: Sage, 2014.

Frieden, J.A: Debt, Development, and Democracy. Modern Political Economy and Latin America, 1965-1985, Princeton: Princeton University Press, 1985. 
Fulek, J.: Rola prawa i etyki w kształtowaniu modelu gospodarczego (Role of law and ethics in shaping the economic model), in: Gasparski, W., Jabłońska-Bonca, J. (eds.), Biznes, prawo, etyka (Business, law, ethics), Warszawa: Akademia Leona Koźmińskiego, 2009.

Hannesson, R.: Debt, Democracy and Welfare State: Are Modern Democracies Living on Borrowed Time and Money?, London: Palgrave Macmillan, 2015.

Holland, D.: Democracies in Crisis: How Do Levels of Democracy Affect Economic Outcomes in Crises of the Developing World?, Users Working Paper, no. 2 (2016).

IMF: Coping with High Debt and Sluggish Growth, World Economic Outlook, 2012.

Kopits, G., Symansky, S.: Fiscal Policy Rules, IMF Occasional Paper no. 162 (1998).

Kothari, C.R.: Research Methodology. Methods \& Techniques, New Delhi: New Age International Limited, 2004.

Kriesi, H., Trechsel, A.H.: The politics of Switzerland: continuity and change, Cambridge, New York: Cambridge University Press, 2008.

Lindholm, R.W.: Debt and Democracy in Germany, The American Journal of Economics and Sociology no. 1 (1946).

Liu, C., Moldogaziev, T.T., Mikesell, J.L.: Corruption and State and Local Government Debt Expansion, Public Administration Review no. 5 (2017), DOI: 10.1111/puar.12711.

Macdonald, J.: A Free Nation Deep in Debt. The Financial Roots of Democracy, New York: Farrar Straus and Giroux, 2003.

Misztal, W.: Homo Ethicus, Homo Moralis. Marii Ossowskiej koncepcja socjologii moralności (Homo Ethicus, Homo Moralis. Concept of the sociology of morality of Maria Ossowska), Warszawa: Scholar, 2017.

Norton, B.G.: Sustainability as the Multigenerational Public Interest, in: Gardiner, S.M., Thompson, A. (eds.), The Oxford Handbook of Environmental Ethics, Oxford: Oxford University Press, 2017.

Oatley, T.: Political institutions and foreign debt in the developing world, International Studies Quarterly no. 1 (2010), DOI: 10.1111/j.1468-2478.2009.00582.x.

Ossowska, M.: Social determinants of moral ideas. Philadelphia: University of Pennsylvania Press, 1971.

Petrażycki, L.: Teorie państwa i prawa w związku z teorią moralności (Theories of state and law related to the theory of morality), Warszawa: PWN, 1959.

Przybyciński, T.: Etyczne i ekonomiczne aspekty państwa dobrobytu (Ethical and economic aspects of the welfare state), Annales. Etyka w życiu gospodarczym (Annalies. Ethics in economic life) no. 3 (2016), DOI:10.18778/1899-2226.19.3.03.

Rachlinski, J.J.: Evidence-based law, Cornell Law Review no. 4 (2011).

Rawl, J.: A Theory of Justice, Harward: Harward University Press, 1999. 
Reinhart, C., Kirkegaard, J., Sbrancia, B.:, Financial Repression Redux, IMF Finance and Development (2011).

Stallings, B., Kaufman, R.: (eds.), Debt And Democracy In Latin America, Boulder: Westview Pres, 1988.

Von Hagen, J.: A note on the empirical effectiveness of formal fiscal restraints, Journal of Public Economics no. 44 (1991).

Ziembiński, Z., Problemy podstawowe prawoznawstwa (Basic problems of jurisprudence), Warszawa: PWN, 1980.

Zimmermann, J.: Aksjomaty prawa administracyjnego (Axioms of administrative law), Warszawa: Wolters Kluwer, 2013.

Zawadzka-Pąk, U.K., Prawnofinansowe instrumenty ograniczania deficytu i długu sektora general government $\mathrm{w}$ państwach europejskich (Financial law instruments for reducing the general government deficit and debt in European countries), in: Lotko, E., Zawadzka-Pąk, U.K.: Prawnofinansowe instrumenty ograniczania deficytu i długu publicznego w Polsce na tle doświadczeń europejskich (Financial law instruments for reducing the general government deficit and debt in Poland in the light of the European experiences), Bialystok: Temida 2, 2018 .

Hunt, G., Accountability. www.freedomtocare.org. 